\title{
A Technology Inclusion in English Teaching and Learning: A Case Study in High and Low Performing Madrasah Aliyahs in Indonesia
}

\author{
$1^{\text {st }}$ Ummi Kultsum ${ }^{1}, 2^{\text {nd }}$ Maya Defianty ${ }^{2}, 3^{\text {rd }}$ Didin Nuruddin Hidayat ${ }^{3}, 4^{\text {th }}$ Agus Sufyan ${ }^{4}$, \\ $5^{\text {th }}$ M. Asrorun Niam Sholeh ${ }^{5}, 6^{\text {th }}$ Arif Zamhari ${ }^{6}$ \\ \{ ummi.kultsum@uinjkt.ac.id ${ }^{1}$, may a.defianty@uinjkt.ac.id ${ }^{2}$, didin.nuruddin@uinjkt.ac.id ${ }^{3}$, \\ agus.sufyan@uinjkt.ac.id ${ }^{4}$, asrorun.niam@uinjkt.ac.id ${ }^{5}$, arif.zamhari@uinjkt.ac.id ${ }^{6}$ \} \\ Sy arif Hiday atullah State Islamic University of Jakarta, Indonesia ${ }^{1,2,3,4,5,6}$
}

\begin{abstract}
This case study focused on how schools utilize technology in the English teaching-learning process and how the school engagement of technology inclusion in the teaching and learning system. This research is significant since mobile technology is essential to support the classroom's teaching and learning process. The study explored low and high-performing Madrasah Aliyah in Bekasi, West Java. The study found that mobile technology is vital to support teachers and students in access to learning sources. However, the two schools provide different purposes for using mobile technology. Lowperforming Madrasah Aliyah indicated that mobile devices' use is essential since the school has not an inadequate handbook for learning. Meanwhile, high performing Madrasah Aliy ah tended to use the technology to up grade the learning sources.
\end{abstract}

Keywords: English teaching and learning, madrasah, mobile technology, technology inclusion.

\section{Introduction}

Technology has always been an essential tool in facilitating the teaching and learning environment. For teachers, technology supports their profession in applying a subject matter in a curriculum. For a student, technology helps them become independent learners and provide a compelling interest in learning [1]. Mobile technology, including cellphones, smartphones, and tablets, is quite popular in the wide world. This device is so handy and efficient to connect people to many interactions and communication [2]-[4]. In the education atmosphere, mobile technology contributes to supporting teachers and students in the teaching and learning process and helps them develop virtual learning, which is called m-learning [2]. Some scholars agree that mobile technology is a useful instrument for pedagogical transformation where some features of the technology provide variations to access valuable learning items [3], [5].

In the Indonesian education context, mobile technology and known as a mobile learning model, are relatively standard applied in many schools. The use of mobile technology is significantly increasing among students [6]. However, some schools tend to avoid using mlearning in their schools - these school pressure policies prohibit students from using any technology devices at school [6]. The integration of mobile technology in the classroom develops students' engagement in learning [7]-[11]. For example, an exploratory study on students in SMPN 10 Semarang, Indonesia conducted by Cahyono and Miftahudin [10] 
revealed that mobile technology, like smartphones, had developed students' involvement in doing mathematic activities. The study also finds that mobile technology has provided proper guidance for students in math trail activities by offering features, including navigation features, help button, and direct feedback on student learning results.

A research development study on Android-based Mobile Learning Media (MLM) conducted by Trimurtini, Liftiah, and Ahmadi [7] indicated that MLM media successfully facilitated elementary students in Kendal, Indonesia. Some findings revealed that the application of MLM media through smartphones provided students' needs in overcoming some challenging materials in the classroom. Moreover, the media also supports the student is working on an independent task at home [7].

However, some studies argue that the use of mobile technology, especially in the classroom, still challenges for both teachers and students to develop their learning engagement [6], [12], [13]. There are at least two demerits of using mobile technology in learning, including inadequate technology literacy for teachers and students and student distraction in operating devices during a learning process [12], [13]. According to Wijaya [13], internal and external factors have been found in operating mobile technology in the classroom. The internal factor is the lack of technology literacy of schoolteachers. This tends to decrease their motivation to use technology in their teaching process. Some students find themselves struggling to adapt to mobile technology-based learning. They are already comfortable with the conventional learning strategy. This may take more time for students to do a transition path from one approach to another.

Moreover, in practical issues, the use of technology in learning might increase plagiarism [13]. Maharsi [12] added that utilizing technology, like google classroom, in learning might distract student study focus. She stressed that although google classroom provides many supports for student learning, online technology has distracted students learning focus. For example, some students are interested in activating social media and other entertainment websites while finishing their tasks. Consequently, it limited their concentration in understanding their task [12].

In the Indonesian madrasah context, the discussion of mobile technology use in the teaching and learning process is still rare. Only a few studies stressed the benefit of applying smartphones in learning [14]-[16]. The limited access to the internet and inadequate facilitation may appear as challenges for a madrasah to utilize technology in the school.

Based on the various background above, this study explores more in-depth about technology inclusion in the English teaching-learning process in Madrasah Aliyah. Further, the study also considers looking up more detail on how the high and low performing Madrasah Aliyah engage with mobile technology in its learning system.

\section{Methodology}

A case study was conducted in two cases of low performing and high performing Madrasah Aliyahs in Bekasi, West Java. An in-depth interview was conducted with madrasah principals and teachers. The interview aimed to gain information on principal and teacher perception of technology inclusion in teaching and learning in the classroom. A thematic analysis was applied to identify two research focuses: technology inclusion in class and comparing low and high-performing Madrasah Aliyahs to engage technology in its learning system. 
The low and high performing Madrasah Aliyah were selected based on madrasah accreditation rate released by the National Accreditation Board/Badan Akreditasi Nasional Sekolah/Madrasah (BAN S/M) [17]. The low performing Madrasah Aliyah was coded as LMA and the high performing Madrasah Aliyah was coded as HMA.

This study involved eight participants, including principal (P1), deputy principal of curriculum affairs (DP1), deputy principal of finance and administration affairs (DP2), deputy principal of student affairs (DP3), two permanent teachers (T1, T2), and two non-permanent teachers (T3, T4). There were 16 participants in total.

\section{Results and discussion}

In this section, the researchers present results according to two themes, namely technology inclusion in the teaching-learning process in Madrasah Aliyah and the comparison between low and high performing Madrasah Aliyah to engage technology in its learning system

\subsection{Technology inclusion in the teaching-learning process in Madrasah Aliyah}

The study found that the two madrasahs: LMA and HMA, allowed teachers and students to use mobile technology, including smartphones or tablets, in the teaching and learning process. However, the two schools described their significant reason for utilizing these devices. According to HMA-T1, mobile technology was significant to support teachers and students to gain more information related to the lesson they had discussed. Thus, the devices were used to strengthen students' knowledge and to understand the learning materials.

As Huda et al. [18] mentioned in their study, Modern Learning Environment encourages teachers and students to gain information supported by digital technology tools such as computers, smartphones, and the internet. These devices facilitate school members, especially students, to strengthen their learning quality in process and outcomes [18]. Xu, Wang, Peng, and $\mathrm{Wu}$ [19] added that providing students with internet access and devices, like tablets and cellphones, can help students improve academic competence and ensure problems get resolved.

According to HMA-P1, most teachers and students had smartphones, and they used them almost every day. Moreover, they, especially students, were already eloquent in using mobile technology to search for any information [18]. Some students even could find many links and sites to support their learning better than teachers. Therefore, the HMA-P1 tended to encourage teachers to update their knowledge in the technology used to support and enhance their teaching sources.

The principals provided some training and tutoring for anyone who needs the implementation of supporting a technology enhancement of teachers. A study conducted by Songbatumis [20] revealed that teachers often struggle to utilize a specific technology to support their teaching strategies and classroom management. Therefore, the madrasah principal hired some technology expertise and facilitated teachers with laptops, so they had convenient access to technology in the teaching process.

However, only teachers were allowed to use mobile technology freely in the school, while it was limited for students. Thus, the use of the internet through mobile technology remains well controlled. This is linked to Xu et al. [19] study that students have behavior to spend 
more time internet surfing through smartphones for entertainment than study, which create s an adverse effect on their academic achievement. Therefore, HMA had tried to control students in the overuse of their mobile technology in the school.

In LMA, mobile technology was used as a significant facility in the learning process since the madrasah lacked learning sources. According to LMA-T1, he used mobile technology in the teaching and learning process because the madrasah did not have a textbook or module for teachers. Therefore, mobile tech became the primary source for both teachers and students in learning the materials.

Further, LMA-T1 stressed that the use of mobile technology in learning was more efficient in leading students to solve the learning problems. It related to Bakri, Marsal, and Muliyati [21] study where utilizing technology media, like android, was proved effective and efficient to support students' learning. Bakri et al. [21] concluded that the integration between textbooks and augmented reality technology is considered appropriate for student learning, mainly physics textbooks.

However, instead of strengthening the textbook with technology, LMA had a different reason. According to LMA-T2, he often combined both textbooks and smartphones in teaching because the textbook no longer matched the current curriculum. Therefore, using mobile technology is more updated and convenient for both teachers and students in solving their learning problems. This echoed by Poláková and Klímová [22] that the use of mobile technology might provide updated materials such as learning apps, information, and news to support teachers and students in the learning process.

The LMA-DP1 also argued that current learning sources like books and other materials did not follow the existing curriculum. This occurred because there was a lack of support for new teaching material in the wake of frequent curriculum changes in Indonesia. He stressed that learning materials from the government usually arrived late after the curriculum had already changed. Therefore, the madrasah could not use its existing books since they did not cover the current curriculum's new concepts. Thus, the existence of mobile technology became significant at this stage. Nevertheless, according to Oktaviana and Rasyid [23], the integration between textbooks and technology in curriculum design is essential in student learning in this modern era. This was proven in their study that technology-based learning, in this case, English, apparently influenced student learning effectiveness and supported teachers to complete their teaching objectives [23].

\subsection{The comparison between low and high performing Madrasah Aliyahs to engage technology in its learning system}

The findings revealed that the two LMA and HMA schools tend to engage mobile technology in the learning systems. The two schools agreed that technology indeed supported and facilitated teachers in developing their teaching materials and encouraged students to gain more information and solution in dealing with their learning tasks. However, the two madrasahs had different challenges in developing technology engagement in their learning system. First, insufficient school facilitation in LMA was slightly hindering teachers and students from applicate the technology. For instance, limited internet access, such as Wi-Fi, wireless, and mobile data, indicated limited both students and teachers to get information through the internet. Dambo and Umah [24], in their view, encouraged that Information and Communication Technology in the school system would promote learners' empowerment and enhancement of student learning performance. 
Some studies mentioned that some technical difficulties appeared on implementing mobile learning, including the availability of latest technology, internet connection, security absence of technical support, insufficient memory, network reliability, small screen, technical support, and technical knowledge [25]-[27]. In Madrasah Aliyah in the Indonesian context, some challenges appeared on using mobile technology. In this study, internet access became a significant matter for teachers and students in operating mobile devices in the classroom. For instance, thee LMA-T1 and T3 stated that madrasah did not provide enough internet access for teaching and learning. Thus, students sometimes met difficulties searching for information through their mobile cellular. Moreover, some students could not get any chances to access internet sites since they did not have enough credit on their smartphones. According to LMA $\mathrm{P} 1$, the madrasah did not have enough budget to increase the fund for the internet. The principal understood that it might hinder the teaching and learning process. Therefore, he encouraged teachers to share offline materials in the class.

On the other hand, HMA almost had no difficulties in accessing the internet in the school. However, the madrasah tended to diminish the use of smartphones and tablets in the madrasah. HMA-P1 stated that the madrasah only allowed technology in the teaching and learning process through a computer and language laboratory and a multimedia room. Teachers and school staff had agreed to this policy. According to HMA-DP3, internet usage limitation might protect students from harmful content, so they can focus on learning in the madrasah.

Further, the deputy stressed that students could still learn online with the control of the teachers. The madrasah control on internet abuse for students tended to be significant to avoid problematic internet use in the school environment. A study conducted by Vadher et al. [28] revealed that in India's context, $16.7 \%$ of students faced various problems influenced by the internet. Some problems appear, such as social anxiety disorder, decreasing sleep quality, and poor quality of life.

Therefore, the use of mobile technology in the learning process was significant. However, the control needed to be done due to protecting students from negative result s of the internet effect. According to HMA-P1, the limitation of mobile technology usage for students was not hinder the online activities in the madrasah. Students seemed to enjoy us ing technology in accessing the internet since students were accustomed to using other devices besides smartphones and tablets to access learning sites.

\section{Conclusion}

In conclusion, mobile technology, such as smartphones, cellphones, or tablets, is essential to support English teaching and learning in the classroom. A case study in two Madrasah Aliyah indicated that the use of technology is necessary to support the learning process. However, since the two madrasahs have a different character, low (LMA) and high (HMA) performing madrasah, the approaches to mobile technology utilizing in schools are different.

LMA preferred to use mobile technology in the teaching and learning process to support teachers and students in finding the sources. This is important since the madrasah lacks textbooks - mobile technology supports both teachers and students some updated learning materials, which covered the learning needs. However, mobile technology inclusion faces a challenge when the madrasah has inadequate internet access to facilitate school members in 
the classroom. Further, the limited cost also becomes a challenge for a madrasah to encourage teachers and students to access the internet in the learning process.

In the case of HMA, the use of mobile technology to students is precisely limited so that they cannot access harmful content from their gadgets. Instead, the madrasah facilitates the use of the internet through computers and laboratories that schools have already filtered. This could be a challenge for some teachers who were unfamiliar with using technology for teaching. Therefore, the madrasah provides facilities in the form of training and guidance to operate technology for teachers. 


\section{References}

[1] D. Ahmadi and M. Reza, "The use of technology in English language learning: A literature review," Int. J. Res. English Educ., vol. 3, no. 2, pp. 115-125, 2018.

[2] M. L. Bernacki, J. A. Greene, and H. Crompton, "Mobile technology, learning, and achievement: Advances in understanding and measuring the role of mobile technology in education," Contemp. Educ. Psychol., vol. 60, p. 101827, 2020.

[3] M. G. Domingo and A. B. Garganté, "Exploring the use of educational technology in primary education: Teachers' perception of mobile technology learning impacts and applications' use in the classroom," Comput. Human Behav., vol. 56, pp. 21-28, 2016.

[4] H. Heflin, J. Shewmaker, and J. Nguyen, "Impact of mobile technology on student attitudes, engagement, and learning," Comput. Educ. Educ., vol. 107, pp. 91-99, 2017.

[5] G. Martiz and M. Recker, "Mobile phone use for English language learning in a Dominican Republic university classroom: a qualitative inquiry," Comput. Learn. Context, vol. 1, no. 1, pp. 1427, 2019.

[6] M. Hanif and S. Asrowi, "Students' access to and perception of using mobile technologies in the classroom: the potential and challenges of implementing mobile learning," J. Educ. Learn., vol. 12, no. 4, pp. 644-650, 2018.

[7] Trimurtini, Liftiah, and F. Ahmadi, "The development of Android-based Mobile Learning Media (MLM) for elementary school students of Kendal Indonesia," in UNNES International Conference on Research Innovation and Commercialization 2018, 2019, pp. 694-705.

[8] A. E. P. Atmojo and A. Nugroho, "EFL classes must go online! Teaching activities and challenges during COVID-19 Pandemic in Indonesia," Register, vol. 13, no. 1, pp. 49-76, 2020.

[9] B. Bukhori, H. Said, T. Wijaya, and F. M. Nor, "The effect of smartphone addiction, achievement motivation, and textbook reading intensity on students' academic achievement," Int. J. Interact. Mob. Technol., vol. 13, no. 9, pp. 66-80, 2019.

[10] A. N. Cahyono and M. Miftahudin, "Mobile technology in a mathematics trail program: how does it works?," Unnes J. Math. Educ., vol. 7, no. 1, pp. 24-30, 2018.

[11] S. Ulfa, "Mobile technology integration into teaching and learning," Int. J. Sci. Technol., vol. 2, no. 1, pp. 1-7, 2013.

[12] I. Maharsi, "Developing EFL Students' learning reflection and self-regulated learning through Google Classroom," in the Proceedings of the 2018 The 3rd International Conference on Information and Education Innovations, 2018.

[13] N. M. C. Wijaya, "Mobile learning in tesol classes in Indonesian high schools contexts: Teachers and students' perspectives," in The Fourth International Conference on English Across Cultures, 2018.

[14] A. M. Albantani, A. Madkur, and A. Rozak, "Foreign language instruction in Madrasah Ibtidaiyah in the technological age: The teachers' voices," in The 2nd International Conference on Islam, Science and Technology (ICONIST 2019), 2020.

[15] K. K. Koderi, "Product implementation of mobile learning media to improve students' Arabic achievement at Madrasah Aliyah in Lampung, Indonesia," Sci. Proc. Ser., vol. 1, no. 2, pp. 76-78, 2019.

[16] R. A. Yudhiantara and A. Saehu, "Mobile-assisted language learning (M ALL) in Indonesian Islamic higher education," IJELTAL (Indonesian J. English Lang. Teching Appl. Linguist., vol. 2, no. 1, pp. 21-31, 2017.

[17] Badan Akreditasi Nasional Sekolah/ Madrasah, "Data Akreditasi Sekolah," 2017. [Online]. Available: https://bansm.kemdikbud.go.id/akreditasi.

[18] M. Huda et al., "Understanding Modern Learning Environment (MLE) in Big Data Era," Int. J. Emerg. Technol. Learn., vol. 13, no. 5, pp. 71-85, 2018.

[19] X. Xu, J. Wang, H. Peng, and R. Wu, "Prediction of academic performance associated with internet usage behaviors using machine learning algorithms," Comput. Human Behav., vol. 98, pp. 166-173, 2019.

[20] A. M. Songbatumis, "Challenges in teaching English faced by English teachers at MTsN 
Taliwang, Indonesia," J. Foreign Lang. Teach. Learn., vol. 2, no. 2, pp. 54-67, 2017.

[21] F. Bakri, O. Marsal, and D. Muliyati, "Textbooks equipped with Augmented Reality Technology for Physics topic in high school," J. Penelit. Pengemb. Pendidik. Fis., vol. 5, no. 2, pp. 113-122, 2019.

[22] P. Poláková and B. Klímová, "Mobile technology and Generation Z in the English language classroom: A preliminary study,” Educ. Sci., vol. 9, no. 3, pp. 203-213, 2019.

[23] F. Oktaviana and Y. Rasyid, "Information, communication, and technology-based English instruction: An ethnography research," in The 1st International Multidisciplinary Conference on Education, Technology, and Engineering (IMCETE 2019), 2020.

[24] B. I. Dambo and H. M. Umah, "Level of awareness of information and communication technology facilities for learning Business Studies in Public Junior Secondary Schools Port Harcourt Metropolis," Int. J. Innov. Inf. Syst. Technol. Res., vol. 6, no. 4, pp. 57-62, 2018.

[25] A. Al-Hunaiyyan, R. A. Alhajri, and S. Al-Sharhan, "Perceptions and challenges of mobile learning in Kuwait," J. King Saud Univ. Inf. Sci., vol. 30, no. 2, pp. 279-289, 2018.

[26] I. A. Qureshi, K. Ily as, R. Yasmin, and M. Whitty, "Challenges of implementing e-learning in a Pakistani university,” Knowl. Manag. E-Learning An Int. J., vol. 4, no. 3, pp. 310-324, 2012.

[27] M. M. C. Shohel and T. Power, "Introducing mobile technology for enhancing teaching and learning in Bangladesh: teacher perspectives," Open Learn. J. Open, Distance e-Learning, vol. 25, no. 3, pp. 201-215, 2010.

[28] S. B. Vadher et al., "Predictors of problematic Internet use in school going adolescents of Bhavnagar, India," Int. J. Soc. Psychiatry, vol. 65, no. 2, pp. 151-157, 2019. 